\title{
Creative and Innovative Education-Based Free Illiteracy Cottage: An Effort to Eradicate Illiteracy Among Suku Anak Dalam in Batanghari Regency

\author{
Saharudin*, Reli Handayani, Siti Amanah
} \\ Department of English Education, Faculty of Teacher Training and Education, Universitas Jambi, Indoneisa
}

Submitted: February 18 ${ }^{\text {th }}$ 2019; Revised: August 20 th 2021; Accepted: August 31 ${ }^{\text {st }} 2021$

\begin{abstract}
Keywords:
Abstract Suku Anak Dalam (SAD) in Kotoboyo Village, Batanghari Regency is

Learning module

Literacy free

lodge

Suku anak dalam

an isolated community group that is currently in a transition phase towards modern life. Guided Village Service activities are carried out to bridge the transition process by providing creative and innovative education-based learning facilities to improve their quality of life. This service is aimed to foster and teach the importance of science by developing the ability to read and write. Therefore, this service establishes the illiterate-free cottage and education group as a means of creative and innovative learning. The learning process involves creating appropriate teaching aids and modules so they can be easily accepted by the target children. In the end, this creative and innovative education-based learning succeeded in increasing cognitive knowledge and learning motivation. Foster children who initially did not know letters and numbers become able to recognize and even write letters and numbers even though they are still in the initial stages. For families and parents of Suku Anak Dalam, the service team finally managed to direct them to actively participate in learning activities and have insight into healthy and clean lives. Many children have also understood the importance of hygiene so that the lives of the inner tribe children are expected to be better.
\end{abstract}

\section{INTRODUCTION}

Educating the country is a lofty objective of Indonesia, as mentioned in Article 4 of the 1945 Constitution, and is one of the purposes of national education that contributes to the nation's welfare. According to the Law of the Republic of Indonesia No. 20 of 2003 on the National Education System, "the national education system must be capable of ensuring equal distribution of educational opportunities, enhancing the quality of education, and ensuring the relevance and efficiency of education management to meet the demands of changing local, national, and global life." Thus, educational changes must be implemented in a planned, focused, and sustainable way.

Suku Anak Dalam (SAD) is an inland communal group that is currently transitioning from forest to city life. As a result, SAD groups must continue to plan their lives to stay current with advances in both daily life and academic life. As a result, they are expected to live in a technologically advanced and dynamic society.

There are 3,198 SAD in Jambi, which are distributed over seven regencies: Merangin, Sarolangun, Tanjab Barat, Tebo, Bungo, and Batanghari (Ibrahim et. al, 2013). Kotoboyo Village is one of seventeen villages in Batin XXIV District, Batanghari Regency, Jambi Province. In 2015, the village had a population of 1,103 residents (Population Composition, 2017). However, this service program focuses on Kotaboyo Village. According to statistics provided by Sorolangun Regency's Central Bureau of Statistics, this village was home to 79 SAD in 2010 (Ibrahim et. al, 2013).

According to current information and studies, the forest area occupied by SAD is diminishing owing to the growth of human populations and the clearance of

ISSN 2460-9447 (print), ISSN 2541-5883 (online)

${ }^{*}$ Corresponding author : Saharudin

Department of English Education, Faculty of Teacher Training and Education, Universitas Jambi, Jl. Lintas Jambi - Muara Bulian Km. 15, Mendalo Darat, Jambi Luar Kota, Muaro Jambi 36361, Jambi, Indonesia

Email: saharudin.fkip@unja.ac.id 
land for oil palm plantations. Their everyday lives are further complicated by the depletion of forest products. This also affects their ability to meet their dietary needs. As a result, they are forced to migrate (melangun) to obtain food in different forest areas when the food supply in one forest region runs out. Indeed, some of them make a living by trading forest products for food (Kasiono, 2017).

Kotoboyo is an example of a village that has already experienced integration. However, the social gaps and restrictions associated with SAD have created an impediment for SAD children to attend the village school. As a consequence, both adults and children in SAD Kotoboyo are unable to recognize letters and numbers. As a result, irresponsible parties have committed widespread fraud by attracting money and then seizing control of their woods. Ironically, they are required to sign (by fingerprint, in this case) a letter of consent that they cannot read. One instance happened when the service team visited the head of SAD Kotoboyo, or more commonly known as Tumenggung, who was always carrying and guarding a piece of paper that turned out to be a certificate of evidence of their forest ownership.

Apart from property disputes, inhabitants of SAD Kotoboyo are frequently duped about economic operations because of their inability to understand the nominal worth of money. As a result, they have no idea how much money they receive when they sell the forest goods they collect.

The advancement of the period, which brings modernism to every part of the territory, undoubtedly poses a significant threat to SAD's existence. Due to a lack of understanding, SAD is more isolated from the surrounding population. As a result, it is necessary to provide them with fundamental education, particularly in reading, writing, and mathematics, for SAD to better their level of living and develop a larger viewpoint. According to Kusnadi (2005), "literacy catalyzes engagement in social, cultural, political, economic, and community empowerment activities, as well as a method of lifelong learning". Given the critical nature of literacy for every human being, it is crucial to provide programs to assist SAD literacy. These literacy services include learning facilities, creative and innovative teaching materials, learning aids, and access to participate in the learning process.

The mentoring approach is tailored to the targeted participants' qualities. The teaching materials are developed creatively and innovatively to facilitate the implementation of the learning process. The teaching materials are delivered via learning modules. According to Prastowo (2012), "Modules are teaching resources that are organized in a way that students can readily understand, according to their age and level of expertise, so that they may study independently with little supervision from educators." It is believed that by developing appropriate teaching materials, excellent learning services can be delivered to SAD. Finally, the assistance is expected to improve the quality of life for SAD in Jambi Province, particularly in the Kotoboyo area, by creating a forum to foster and educate them about the importance of science, particularly in the context of literacy, through the establishment of an Islamic boarding school based on creative and innovative education to eradicate illiteracy.

According to Law Number 20 of 2003 on the national education system, the education route in Indonesia is composed of formal, informal, and nonformal education. Each of the three is designed for participants with distinct qualities, making them inseparable in the endeavor to establish a community. Non-formal education includes literacy education, which targets illiterate individuals in areas such as literacy, numeracy, Indonesian language, and basic education. This literacy instruction is governed by law, specifically Presidential Instruction Number 5 of 2006 on the action to eradicate illiteracy and Minister of National Education Regulation Number 50 of 2007 on the management of education by district/city governments.

As a part of the universal right to an education, indigenous peoples living in rural locations are included in the illiteracy eradication program's target population. This is mentioned in Law Number 20 of 2003. Chapter 4 Article 5 Paragraph 3 states that "citizens living in distant or underdeveloped regions, as well as indigenous peoples living in remote locations, have the right to receive special service education." Special service education is defined further in Article 32, Paragraph 2, which states that "special service education is education for students who live in remote or underdeveloped areas, remote indigenous communities, and/or who are affected by natural or social disasters, or who are economically disadvantaged."

In practical terms, SAD never resides in a single location. They are always on the move, and thus never get the opportunity to receive a formal education. Therefore, one approach is to provide specific services in the form of non-formal education in SAD's houses. This service is expected to increase the quality of SAD by providing more productive human resources capable of reading, writing, and counting. Finally, it is expected that their well-being will improve.

SAD is defined by Hariyadi \& Harmoko (2013) as "a group of indigenous Jambi people who occupy particular areas of Jambi Province's lowland tropical rain forest." Suku Anak Dalam is inextricably linked to the forest, both as a source of life and as their home and 
hometown (Hariyadi \& Harmoko, 2013). Additionally, woods hold a great deal of cultural value (Prasetijo, 2011). Forests are critical to the long-term viability of SAD life (Ibrahim et al., 2013). Forest function changes may potentially pose difficulties for SAD and perhaps neighboring populations.

At least two theories exist about the origins of SAD. According to the first opinion, SAD's progenitor is Maalau Sesat, who left his family following a conflict (Hutan adalah Rumah, 2017). According to the second view, SAD's forefathers are descendants of the Pagaruyung group, who moved in pursuit of a better way of life (Hutan adalah Rumah, 2017). The occurrence of numerous terms that are related to Minang language lexicon bolsters the second opinion.

Suku Anak Dalam is sometimes referred to as Orang Kubu (people who refuge) or Orang Rimbo (people of the forest). However, the term Orang Kubu for SAD carries a negative connotation: it is repulsive, filthy, and foolish (Kasiono, 2017). This reference was also found in several colonial scripts (Handini, 2005; Marmoah, 2010; Kasiono, 2017). Meanwhile, the term Orang Rimbo first appeared in Mutholib Soetomo's dissertation entitled Orang Rimbo: StructuralFunctional Study of Isolated Communities in Makekal, Jambi Province in 1995 (Hutan Adalah Rumah, 2017) while the Indonesian government, through the Ministry of Social Affairs, coined the acronym SAD (Kasiono, 2017).

Instill knowledge among remote tribes is not simple. Numerous hurdles and impediments frequently thwart these endeavors. Nonetheless, this endeavor must be maintained. This is a need in today's fast-paced modernization. Education is the midway that they must learn to adapt to changing circumstances.

$\mathrm{SAD}$ is one of Indonesia's most secluded tribes. According to Daulay (2013), the SAD's economic situation lags far below that of other ethnic groups. Indeed, their status before the law is frequently precarious due to a lack of documentation of land ownership, a lack of education, and a lack of skills. Because they cannot read, write, and count, SAD is frequently deceived in terms of economic affairs (Baharudin, 2010). The problems associated with SAD have been explored and can be alleviated via education.

SAD need education to better their level of living, particularly in light of the problem of diminishing forest area. According to Kasiono (2017), SAD "need to be supplied with an education based on their own culture, particularly livelihoods, so that they may survive in the future even as the forest environment in which they live becomes increasingly scarce and no longer supplies adequate food."

Government initiatives have been undertaken to improve SAD education. Nonetheless, efforts to 185 www.jurnal.ugm.ac.id/jpkm inculcate such information are frequently limited. SAD usually opposes the government's education efforts for the following grounds.

1. Formal education is seen negatively since it contradicts what Tumenggung and their parents teach. They do not require formal schooling since it would divert their time away from forest activities (Hidayat, 2013).

2. SAD prefer to wander rather than sit and listen to the teacher's lectures (Hidayat, 2013).

3. Education is seen negatively by the culture. Education is said to have the potential to "destroy their customs in general and also create dread of calamity as a result of God's curse" (Baharudin, 2010).

4. There is a proverb in SAD that "being dumb is better than being smart and using it to deceive others" (Baharudin, 2010).

Apart from these factors, the government and various elements of society have a responsibility to support the elimination of illiteracy in the SAD community through non-formal education. The organizers of learning activities have employed a variety of strategies relating to individual approaches and learning methodologies approaches. According to Hidayat (2013), SAD students are pleased to go to school since they will receive meals and snacks. Additionally, changes to learning approaches such as teaching materials and other modifications may be necessary to entice supported participants to learn. Innovations and suitable learning techniques must be implemented because what they learn is frequently novel to SAD, distinct from what they acquire when living in the forest.

\section{METHOD}

The service aims to foster and teach SAD in Kotoboyo Village, Batin XXIV District, Batanghari Regency, Jambi province the importance of science, particularly in the context of literacy, through the establishment of freeilliterate cottage based on creative and innovative education to eradicate illiteracy. The mechanisms are as follows:

1. Determining target foster group,

2. Analyzing problems and needs of assistance,

3. Designing the programs and learning materials,

4. Monitoring and evaluating accomplished activities.

A field survey to select foster groups and determine the location of SAD was carried out on June 21 to 22, 2018. Through coordination with the waris (non-SAD people who live close to SAD's settlement forest and are appointed to bridge communication between the tribe and outer community) and head of $\mathrm{SAD}$, problems, and needs for the program could be identified, and a more specified learning purpose could be determined. This technique is following definition of 
purposive sampling of Sugiyono (2010), which refers to the technique as a means to select subjects based on certain considerations, such as choosing one with the highest understanding about the observed topic, or one with the largest authority, thus allowing the researchers to explore the target object/situation, or in this case, the foster community. The data of this research were collected with the help of a waris group of SAD in Kotoboyo Village since they interact more actively and communicate well with the target community.

The next step to be carried out related to the learning program and teaching materials is technical preparation. This step involves procurement of learning equipment, literacy cottage facilities, learning modules, food donations, and transportations to visit their location. Food and clothing donations were made to attract the target community to gather and learn with the team. After the preparation was completed, foster activities were started by elaborating the activity plans and followed by learning activities.

The learning materials were developed creatively and innovatively to facilitate comprehension of reading, writing, and calculating. Creative learning refers to a technique that utilizes various properties and calculation modules specifically designed to spark students' learning interests. Innovative learning, on the other hand, refers to the efforts of the service team to educate SAD parents without explicitly requesting them to learn. As observed at the location, the parents always rejected the opportunity to study because they believed they were too old for it. However, they also did not want outsiders to be around their children, thus, they always closely monitored their children's learning activities. By applying the active participation method, those parents eventually became interested and expressed their willingness to participate in learning.

The learning models implemented to SAD group are as follows:

1. Introducing and teaching alphabets through writing, reading, and recognizing numbers.

2. Introducing and teaching simple calculations using a creative and innovative concept.

3. Fostering and empowering them by nurturing a clean and healthy lifestyle.

4. Providing a learning site in the form of a freeilliterate cottage.

5. Maintaining program sustainability by focusing on character-based learning so that they become able to socialize well.

\section{RESULT AND DISCUSSION}

The outcome of this community service is the establishment of a creative and innovative educationbased free-illiterate cottage to eradicate illiteracy among the SAD in Kotoboyo Village, Batin XXIV District, Batanghari Regency.

\subsection{Problem identification and needs analysis}

This study's problem identification and analysis involve three aspects. 1) In term of social life, the assisted community are welcome to interact with outer communities, making between the service team and them easier. 2) They have a huge and consistent interest in learning as they hope to develop their understanding, not only in terms of reading, writing, and calculating skills but also in terms of maintaining cleanliness.

In terms of learning activities, the SAD children demonstrated great learning enthusiasm. This is marked by the huge number of children and family members who attended each session even though the travel distance and natural conditions they had to go through were challenging. On the other hand, in terms of sanitation, this group does not have the habit of showering, nor the awareness of self-sanitation, thus the service team had to teach the children to wash their hands and brush their teeth. This finding supports Rasyid (2021) explanation that individual hygiene and sanitation are efforts to maintain one's health and cleanliness, as influenced by social practice, socioeconomic status, and knowledge.

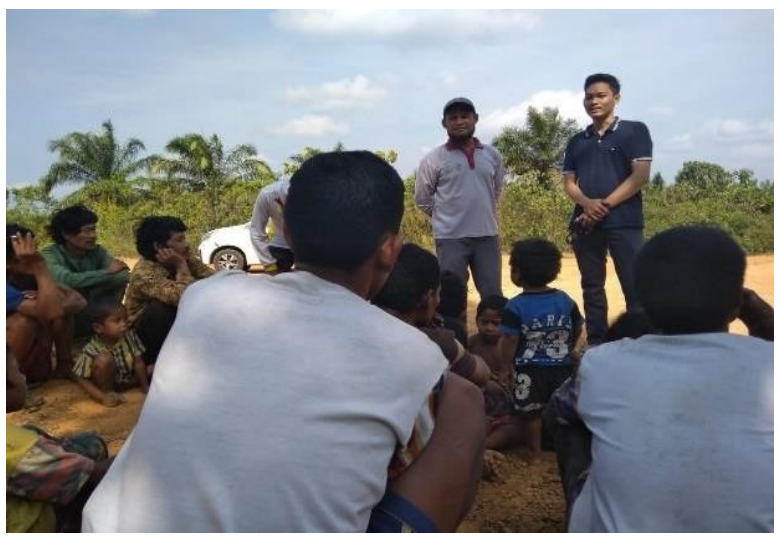

Figure 1. Learning activity

In the first meeting, we were assisted by waris of $\mathrm{SAD}$ and several village administrators as shown in Figure 1. From this meeting, we noted that SAD Kotoboyo consists of 34 heads of families, all of whom are left behind in terms of education. Apart from the factors of tradition and habit common of isolated community groups, this impoverishment is worsened by geographical factors and inadequate facilities and infrastructures. Their area was also difficult to reach even with double axle four wheels vehicles.

In our first visit, the Foster Village team did not prepare the learning activities yet. Instead, we conducted dissemination regarding their purpose and introduced ourselves to the waris and families of SAD We brought groceries consisting of rice, sugar, and instant noodles, and decent clothes to initiate 
interaction with them. The groceries and clothes were then distributed to them. The SAD needs the groceries brought by the visiting volunteer team. This distribution also served as the team's introductory greeting to them. Every time the team visits their settlement, they request some food or souvenirs.

The SAD is a nomad. They use tarpaulin or leaves as cottage ceilings. The community in our observed location has received government assistance to build livable houses. However, due to several natural factors and their daily hunting, they had to go deeper into the forest. Nowadays, coal mining is also operating in Hajiran Village, causing their settlement area to be contaminated. The river they usually use for bathing and drinking got contaminated and its color changed to black, making it no longer suitable for use. In the end, they had to move out of their established houses to other places they deem proper for living.

\subsection{Free-illiterate cottage}

A free-illiterate cottage was built based on arranged financial planning. Its establishment started with field observation and consultation with the waris and the community members of SAD. After a land area was selected by taking into account easiness and accessibility aspects, the building location and design were also determined by the community service team. Lastly, the building process was ready to be carried out. The following is a photograph documenting the building process.

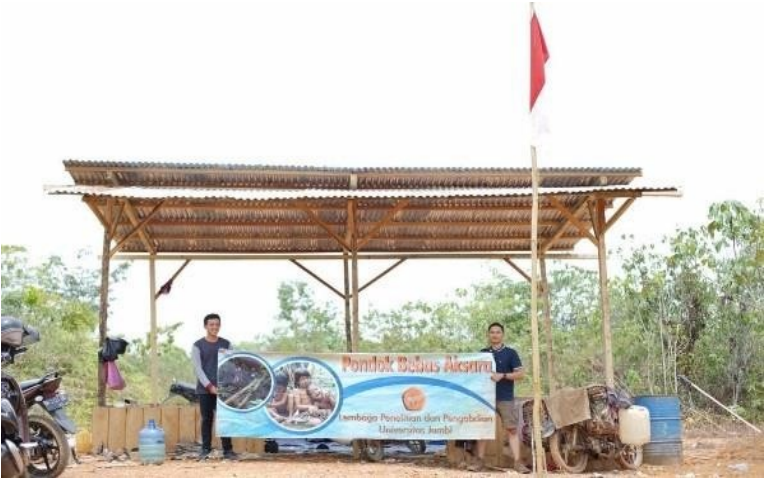

Figure 2. Using free-illiteracy cottage for Independence Day commemoration ceremony on 17 August 2018

Since the beginning of its establishment, this cottage was collectively built by the community service team, the foster community, and SAD waris and family members. This cottage was first used to hold an Independence Day Commemoration Ceremony on 17 August 2018 as shown in Figure 2, attended by some SAD family members and village administrators. This ceremony was held enthusiastically because it was a new experience for them. Through this ceremony, the community service team attempted to nurture nationalism among SAD groups.

\subsection{Learning Methods for SAD Education in Kotoboyo}

The learning methods incorporated to foster SAD Kotoboyo are creative and innovative learning, which emphasizes the active participation of assisted children to practice directly using prepared learning properties and materials. This method was implemented so they could easily understand the materials.

The foster children's age ranges from 5 to 17 years old. The learning activities were carried out altogether because all of them have not learned reading and writing. There were only a few children who have learned simple calculations. However, they have not been able to write alphabets and read well. Therefore, the team used similar props and materials for all of them so that they could easily grasp the knowledge.

The learning equipment prepared and used for the foster process are as follows.

1. Stationaries, such as pencils, pens, and colored pens.

2. Learning modules.

3. Whiteboard

4. Alphabets and number props, both in the form of posters and pieces.

5. Magnet board for easier writing

6. Other learning materials

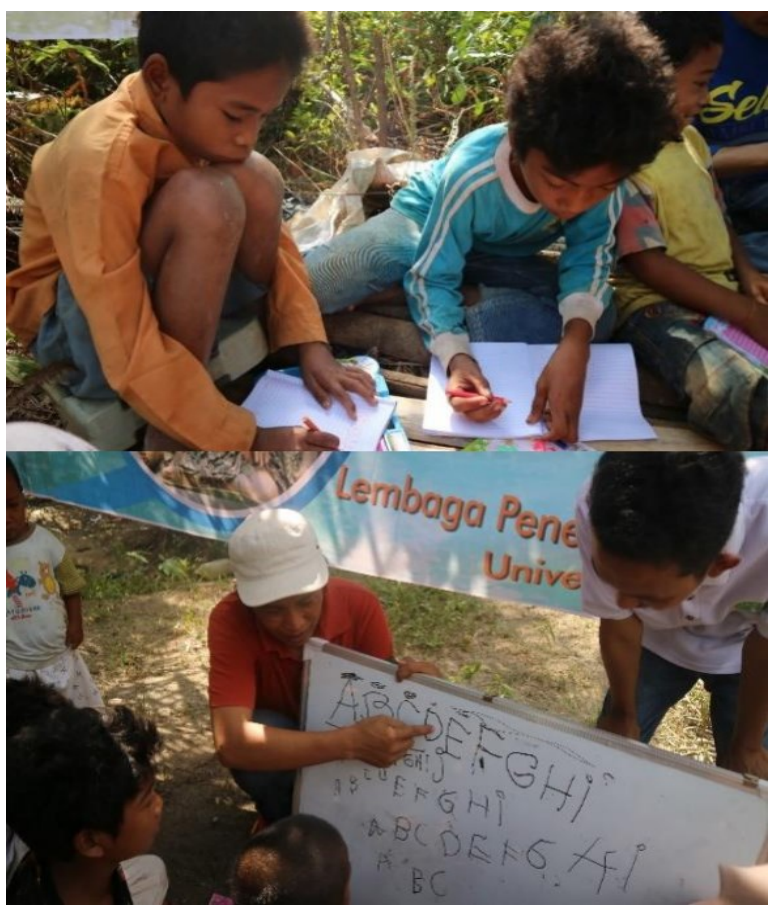

Figure 3. Introducing alphabets and numbers

The learning activities were carried out in several steps, and each step continues to the next based on the level of target materials. The material starts with an introduction of alphabets and numbers for children as shown in Figure 3. A challenge in this step is that the children relatively have not been exposed to alphabets and numbers. With different age levels, the learning 
process was carried out slowly and used a personal approach. The learning consists of six meetings with continuous materials. The fostering team brought several stationaries, learning properties, and learning media needed to introduce alphabets and numbers.

The learning module as shown in Figure 4 was also utilized in the process because it seemed that the foster children were able to understand numbers and alphabets after several meetings. This module focuses on developing the ability of simple calculation. In this meeting, the children seemed to participate enthusiastically. The module was used to help them grasping numbers and calculating operations, especially addition and subtraction. During this process, we provided snacks as rewards for those who could write correctly. Another interesting thing in each meeting is the parents' active participation by sitting around and paying attention to the material while expressing "We also want to join. We also want to be able to read and calculate".

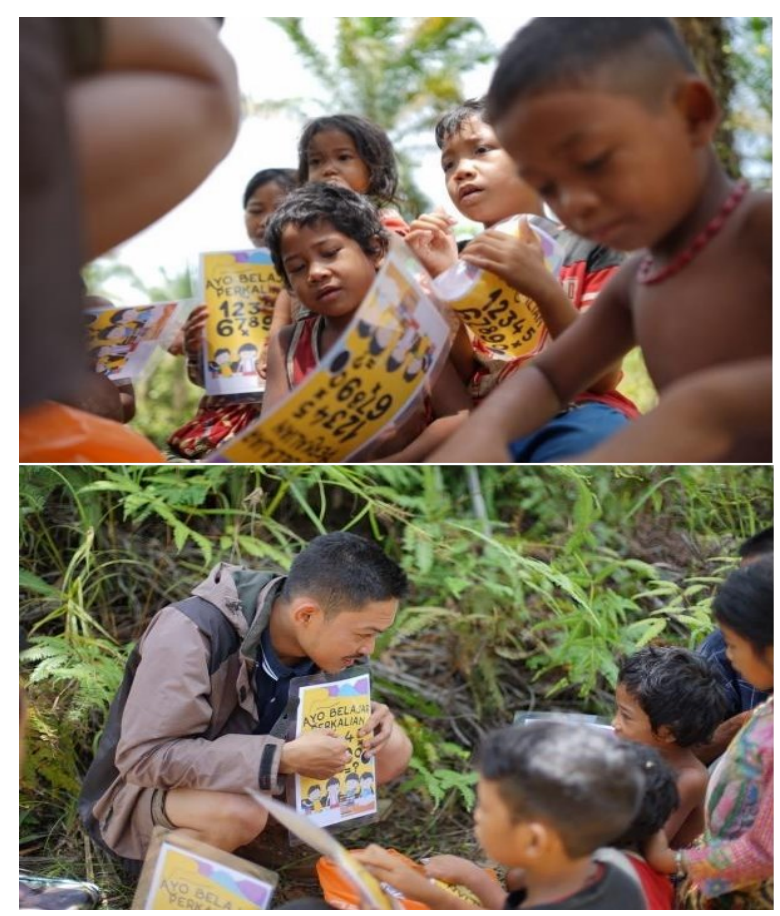

Figure 4. A Learning process using a module

\section{CONCLUSION}

Based on the results of the foster program for SAD, it can be concluded that:

1. The free-illiteracy cottage that was designed and consulted with SAD was built successfully and used in the creative and innovative learning process to eradicate illiteracy among SAD in Kotoboyo Village.

2. The creative and innovative education successfully facilitated SAD learning because it does not emphasize procedural aspects, thus allowing foster children to easily grasp the knowledge. They enjoyed learning about using properties and media that present concrete objects.

3. Their cognitive understanding has improved, from not recognizing letters and numbers to being able to recognize and write them.

4. The children showed enthusiasm for learning. Their learning motivation was also incredible.

5. The foster program was able to direct SAD families and parents towards a healthy and clean lifestyle, as well as empower them so they can protect their land rights from outsiders.

6. Every foster program to be implemented in SAD community in Kotoboyo Village should pay attention to the condition of equipment, transportations used to reach the location, and weather prediction in the village. This is because, during rainfall, the location is inaccessible using regular vehicles.

Several recommendations are made upon the completion of this service. Those are:

1. For the next community service, the problems encountered by the current program can be used as references so that a sustainable service to SAD can be carried out.

2. For the public, the outcomes of this service can give insights that $\mathrm{SAD}$ is a community that can socialize well. Therefore, the public needs to pay more attention.

\section{ACKNOWLEDGEMENT}

We would like to thank the Rector of Jambi University, the Chairman of Research and Community Service Foundation, the waris of SAD Group in Kotoboyo Village, Kotoboyo Village Administrators, SAD Community, and the Volunteer Team of SAD Community Care who have provided financial assistance and facilities that the Foster Village service was accomplished successfully.

\section{REFERENCES}

Hutan adalah Rumah dan Sumber Penghidupan Kami Kesaksian Tumenggung Tarib "Orang Rimbo" Provinsi Jambi. Dikutip dari http://www.aman.or.id/wpcontent/uploads/2014/05/KesaksianTumenggung-Tarib Orang-Rimba padaSidang-Gugatan-UU-Kehutanan-ke-MK-1.pdf

Komposisi Penduduk dan Beban Ketergantungan. Dikutip dari http://kecbatin24.batangharikab.go.id/dataumu $\underline{\mathrm{m} / 2 / \text { kependudukan. }}$.

Baharudin, Erwan. (2010). Pendidikan Suku Anak Dalam: Suatu Perbahan Dari Paradigma Positivistik Ke Konstruktivisme. Forum Ilmiah, 7(2), 100-104.

Daulay, Asnelly Ridha. (2013). Dinamika Pemanfaatan Hutan oleh Suku Anak Dalam Bathin IX di 
Dusun Senami Kabupaten Batanghari. Jurnal Bina Praja, 5 (1), 35-42. doi: 10.21787/JBP.

Hariyadi, Bambang, Dedi Harmoko. (2013). Pengelolaan Buah-buahan pada Masyarakat Suku Anak Dalam. Prosiding Semirata FMIPA Universitas Lampung.

Hidayat, M. Syamsul. (2013). Penerimaan Suku Anak Dalam (SAD) terhadap Pendidikan. Skripsi Jurusan Ilmu Komunikasi Fakultas Ilmu Sosial dan Ilmu Politik Universitas Diponegoro.

Ibrahim, Muhammad, Gunawan Kamil Pasya, Djakaria M Nur. (2013). Kehidupan Suku Anak-Dalam di Kecamatan Air Hitam Kabupaten Sarolangun. Antologi Pendidikan Geografi, 1 (3), 1-15.

Kasiono. (2017). Potensi Usaha dan Pendidikan Kecakapan Hidup Berbasis Budaya (Mata Pencaharian) 'Suku Anak Dalam'. Jurnal Ilmiah Dikdaya, 7 (2), 74-91.

Kusnadi, dkk. (2005). Pendidikan Keaksaraan Filisofi, Strategi, Implementasi. Jakarta: Departemen Pendidikan Nasional direktorat Pendidikan Luar Sekolah Direktorat Pendidikan Masyarakat.

Prasetijo, A. (2011). Serah Jajah dan Perlawanan Etnografi Orang Rimba di Jambi. Jakarta: Wedatama Widya Sastra.

Prastowo, A. (2012). Panduan Kreatif Membuat Bahan Ajar Inovatif. Yogyakarta: DIVA Press.

Rasyid, M. et.al. (2021). Socialization of Personal Hygiene for Danu's Tofu Home Industry Workers in Alue Peunyareng, Meureubo Subdistrict, West Aceh Regency, Aceh. Indonesian Journal of Community Engagement, 7 (2), 66-69.

Sugiyono. (2010). Metode Penelitian Pendidikan Pendekatan Kuantitatif, Kualitatif, dan $R \& D$. Bandung : Alfabeta. 